Netsu Bussei 2 [1] (1988) 53/58

\title{
[論文】 HEAT CAPACITY, HEAT OF TRANSITION, AND THERMAL CONDUCTIVITY OF PENTAERYTHRITOL AND ITS SLURRY
}

\author{
Yoshio TAKAHASHI, Masayuki KAMIMOTO, Yoshiyuki ABE \\ Electrotechnical Laboratory \\ 1-1-4 Umezono, Tsukuba, Ibaraki 305 \\ Yuji NAGASAKA, Akira NAGASHIMA \\ Department of Mechanical Engineering, Keio University \\ 3-14-1 Hiyoshi, Yokohama 223
}

\begin{abstract}
Pentaerythritol is a promising latent thermal storage material with transition temperature $188^{\circ} \mathrm{C}$. Use of slurry of pentaerythritol and heat transfer oil (Hitherm PS-5) can enhance heat conduction in the storage material. In the present study, heat capacity and heat of transition were measured by differential scanning calorimetry on pentaerythritol and Hitherm PS-5. Thermal conductivities of Hitherm PS-5 and the slurry with 70 weight $\%$ of pentaerythritol were measured by the transient hot-wire method. The data of heat capacities and thermal conductivities were correlated by linear equations. The thermal conductivity of the slurry showed a discontinuity at the transition temperature due to a change in crystal structure.
\end{abstract}

\section{INTRODUCTION}

The latent heat of pentaerythritol $\left(\mathrm{C}\left(\mathrm{CH}_{2} \mathrm{OH}\right)_{4}\right)$ at the transition point of $188{ }^{\circ} \mathrm{C}$ is as large as the heat of fusion of ice. The heat of transition is about $300 \mathrm{~kJ} / \mathrm{kg}$ [1-4], although it is different from sample to sample depending on the purity of the material. The temperature range around 188 ${ }^{\circ} \mathrm{C}$ is quite important for process heat utilization because of the possibility of steam generation.

From thermoanalytical evaluations, sakamoto et al.[2] concluded that pentaerythritol is a promising latent thermal storage material in the temperature range between 150 and $200{ }^{\circ} \mathrm{C}$.

In order to make effective use of pentaerythritol as a latent thermal storage material, the authors et al. proposed a few active-heat-exchange thermal storage devices $[5,6]$ and an encapsulated-type (passive) storage device [6]. For both the active and passive heat exchange devices, use of pentaerythritol slurry with heat transfer oil (for example, Hitherm PS-5) is recommended to enhance the heat conduction in the storage materials.

Heat capacity, latent heat, and thermal conductivity are fundamental thermophysical properties for thermal storage materials. They are strongly related to energy density, power density, temperature efficiency, and so on. Data of such thermophysical properties are therefore needed in various stages of R\&D of storage systems.

Heat capacity and latent heat of the slurry are usually the sum of those properties of the component materials. on the other hand, it is difficult to estimate thermal conductivity of the slurry accurately from the values of the components. In the present study, measurements of heat capacity and heat of transition were made on the components : pentaerythritol and Hitherm PS5, and thermal conductivity was measured on the slurry and Hitherm PS-5.

\subsection{Samples}

\section{EXPERIMENTAL}

Pentaerythritol was supplied by Koei Chemical Co., Ltd. Its purity was determined to be 99.7 \% by the standardized method (Japan Industrial Standard). The diameter of the crystal was around 0.3 to $0.8 \mu \mathrm{m}$. Pentaerythritol was dried at $110^{\circ} \mathrm{C}$ for $24 \mathrm{~h}$ before measurements. For Hitherm PS-5 (Nippon Oil Co., Ltd., alkyldiphenyl ethane), measurements were made on a fresh sample as was received.

2.2 Apparatus and Procedure

2.2.1 Heat capacity and heat of transition A Perkin-Elmer DSC-2 was used. Data acquisition and processing were made with a data logger (Hewlett Packard HP 3497A) and a personal computer (Hewlett Packard HP 9816S).

An aluminum sample pan for a volatile specimen was used because of high vapor pressure of pentaerythritol and the Hitherm PS-5. Mass of the specimen was measured after each DSC measurement to check the vaporization of the specimen due to a possible break of the sealed sample pan.

Heat capacity measurements were made in a usual way by observing DSC base lines for an empty pan, a reference material (sapphire), and a sample. An example of the measured signals is 
shown in Fig. 1. Correction was made for weight difference between the pan for the refierence and the pan for the sample by using the specific heat capacity data of aluminum. Specific heat capacity of a sample cs was calculated by the following equation:

$$
\frac{W_{\mathrm{R}}\left[\left\{Y_{\mathrm{S}^{-}}\left(\frac{c_{\mathrm{P}} \Delta W_{\mathrm{P}}\left(Y_{\mathrm{R}}-Y_{\mathrm{B}}\right)}{c_{\mathrm{R}} W_{\mathrm{R}}}\right)\right\}-Y_{\mathrm{B}}\right] c_{\mathrm{R}}}{W_{\mathrm{S}}\left(Y_{\mathrm{R}-Y_{\mathrm{B}}}\right)},
$$

where $W_{R}$ and $W_{S}$ are weights of the reference and the sample, and $\Delta W_{P}$ is the weight difference between the pan for the reference and that for the sample. In this study, the weights of the samples were. $12.73 \mathrm{mg}$ and $8.91 \mathrm{mg}$ for pentaerythritol and Hitherm PS-5, respectively. $\quad c_{R}$ and $c_{P}$ are the specific heat capacities of the reference and the blank (empty pan), respectively. $Y_{\mathrm{S}}, Y_{\mathrm{R}}$, and $Y_{\mathrm{B}}$ are the DSC signals for the sample, reference, and the blank, respectively. The accuracy of our DSC measurements is estimated within $+2 \%$

The temperature increment in each scan was $40 \mathrm{~K}$ for Hitherm PS-5 and 40, 50 , or $60 \mathrm{~K}$ for pentaerythritol depending on the temperature range. The heating rate was $5 \mathrm{k} / \mathrm{min}$. The DSC data was recorded at every 12 seconds in the steady state and at every 3 seconds in the transition region; therefore, specific heat capacities were determined at every $1 \mathrm{~K}$ in the steady state and at every $1 / 4 \mathrm{~K}$ in the transition region.

Heat of fusion was determined from the integration of the specific heat capacity curve thus obtained. This method using the sapphire as a reference material was proposed by one of the authors (YT)[7]; the latent heat can be determined more accurately than the conventional latent heat measurement by DSC using reference metals with a known latent heat such as indium.

2.2.2 Thermal conductivity The principle of the thermal conductivity measurement is based upon the transient hot-wire method. This method is well known and the comprehensive paper on the theory and the error analysis is available [8], then only the principle of the measurement and the present experimental apparatus are described here.

In the idealized model, the transient hot-wire apparatus consists of a vertical thin metallic wire immersed in a liquid sample where the wire acts both as an electric heating element and a resistance thermometer. Initially at temperature $T_{0}$, a step voltage is ap- plied at time $t=0$ across the wire. Then the transient temperature rise of the wire can be written as follows;

$$
\begin{aligned}
\Delta T(t) & =T(t)-T_{0} \\
& =(q / 4 \pi \lambda) \ln \left(4 \kappa t / a^{2} C\right),
\end{aligned}
$$

here $\lambda$ : thermal conductivity, $k$ : thermal diffusivity, a: a radius of the wire, $q$ : heat generation per unit length of the wire and $C=\exp \gamma=1.781 \ldots$ where $\gamma$ : Euler's constant. According to Eq.(2), the thermal conductivity can be measured by a straight line for a plot of $\Delta T(t)$ against in $t$ and $q$ given by

$$
\lambda=(q / 4 \pi) /(d \Delta T / d \ln t) .
$$

When natural convection occurs during the measurement, it can be detected as a convex curvature off the straight line. Therefore this method has the advantage to eliminate the error due to onset of natural convection.

Figure 2 shows a block diagram of the present fully automated transient hot-wire apparatus [9]. The apparatus consists mainly of six components: microcomputer, a heater power controller, a digital voltmeter (DVM), a bridge with selection switches for sequence control, a power supply and a hot-wire cell with thermostatic bath.

We have featured the following functions for the present apparatus. (1) The time of onset of natural convection can be detected for an individual run, then the thermal conductivity is calculated using the temperature rise between appropriate time intervals. (2) All sequential switchings and resistor adjustment procedures can be performed. (3) Temperature of the thermostatic bath can be controlled, and after filling a liquid sample in a cell, the

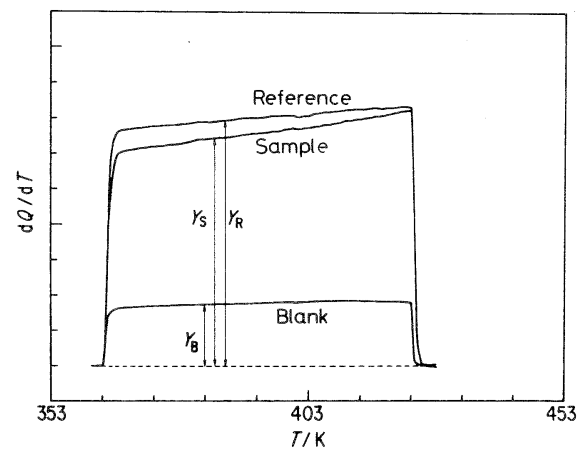

Fig. 1 An example of DSC signals for an empty pan (blank), a pan with a reference (sapphire), and a pan with a sample (pentaerythritol). 
apparatus can start to take measurement. In other words, the apparatus can measure the thermal conductivity of dielectric liquids without any manual procedures except for the sample preparation.

A cross-sectional view of the hotwire cell together with a vessel is shown in Fig. 3. The main frame of the hot-wire cell consists of SUS rods 11 on whose ends alumina discs 6 are fastened. The platinum wire ( $9 \overline{9} .99 \%)$ of $30 \mathrm{\mu m}$ in diameter 10 and of about 100 $\mathrm{mm}$ in length is soldered between two platinum hooks 4 with an axial stress of predetermined magnitude. Two potential leads 5 of the same wire are spot welded at positions $15 \mathrm{~mm}$ from each end of the wire in order to eliminate the end effects.

The relation of the temperatureresistance of the wire is calibrated

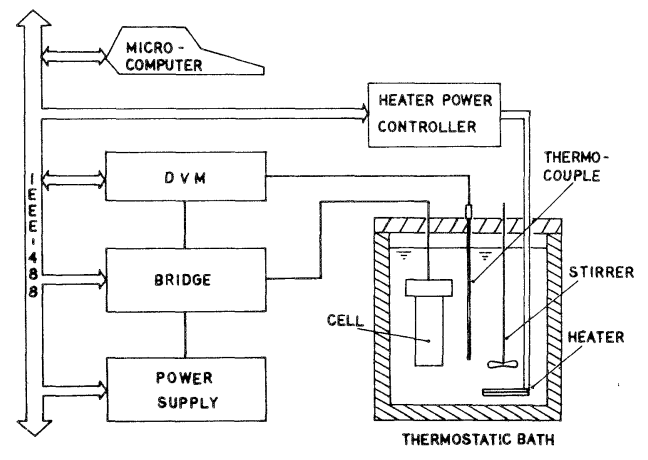

Fig. 2 Experimental apparatus for thermal conductivity measurements.

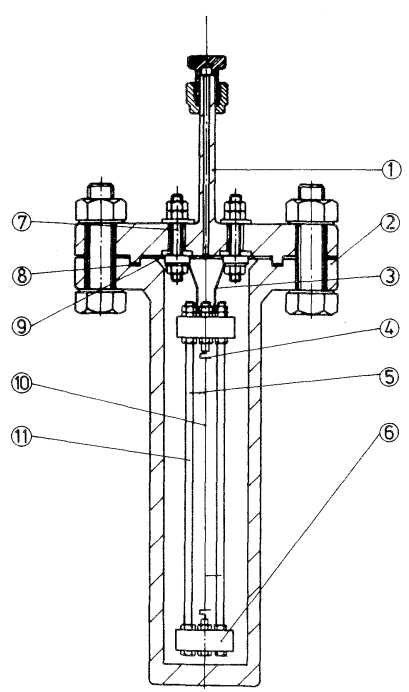

(1) Sample inlet

(2) Vessel

(3) Electrical leads

(4) Pt hook

(5) Potential leads

(6) Alumina disc

(7) Terminal

(8) Cu packing

(9) PTFE sea1

(10) Pt wire $\$ 30 \mu \mathrm{m}$

(11) SUS rod

Fig. 3 Hot-wire cell with vessel. in situ in the temperature range from 0 to $200{ }^{\circ} \mathrm{C}$ in advance. The temperature was measured with the aid of a standard resistance thermometer which was calibrated on IPTS-68. In order to confirm that the apparatus operates in accordance with the theory, the thermal conductivity of toluene was measured repeatedly and compared with the values recommended by the present authors [10].

In the course of filling the slurry of pentaerythritol and Hitherm PS-5 in the cell, a considerable care was taken because the cell was originally designed only for liquid. The hot-wire itself is so fragile that the cell cannot be inserted directly into the slurry contained in the vessel. Therefore the cell was fixed in the vessel first and then small crystal of pentaerythritol was filled very slowly through the sample inlet 1 in Fig. 3. After filling the maximum possible amount of pentaerythritol without giving any detectable stress on the wire, Hitherm PS-5 was poured from the inlet in almost like a drop by drop process to prevent mixing of air in the slurry.

The apparent final weight fraction of pentaerythritol was approximately 70 \%, which is close to the value needed for encapsulated type storage devices. Even with this procedure for the sample preparation, small amount of residual air near the wire could not be avoided. Then the measurement was repeated on heating and cooling processes for several times. The final results were obtained on cooling after through the crystalline transition of pentaerythritol at $188{ }^{\circ} \mathrm{C}$. The reason for this is that small crystals of pentaerythritol stick together after the phase transition and this condition might resemble that in actual thermal storage systems.

\section{RESULTS AND DISCUSSION}

\subsection{Heat Capacity and Heat of Transi-} tion

3.1.1 Pentaerythritol Figure 4 shows the specific heat capacity data on pentaerythritol and the integrated enthalpy change curve; a part of the data are listed in Table 1 with $5 \mathrm{~K}$ intervals. The data points are plotted on an enlarged scale in Fig. 5 together with the results by Nitta et al. [1]. Note that the specific heat capacities in the transition temperature range are apparent values since the temperature on the abscissa is not corrected. From the extrapolated onset temperature $T_{t}$, the transition temperature was determined to be $185.6^{\circ} \mathrm{C}$. The heat of transition was determined to be $285 \mathrm{~J} / \mathrm{g}$ from the difference in the extrapolated 
3.1.2 Hitherm PS-5 The measured specific heat capacity data are shown in Fig. 6 together with the catalogue values [11]; the data are also listed in Table 2 with $5 \mathrm{~K}$ intervals.

The catalogue values show a large discrepancy from the measured ones. Such discrepancies are also reported on many kinds of heat transfer oils $[12,13]$. The specific heat capacity data measured in this study were fitted to the following linear expressions. The standard deviation from the smoothed values is less than $0.3 \%$;

$$
\begin{array}{r}
c_{p} / \mathrm{Jg}^{-1} \mathrm{~K}^{-1}=0.7293+0.00321 \times(T / \mathrm{K}) \\
334 \mathrm{~K}<T<513 \mathrm{~K} .
\end{array}
$$

\subsection{Thermal Conductivity}

3.2.1 Hitherm PS-5 The results of the measurements are listed in Table 3 . The temperature rise of the platinum wire was about $1 \mathrm{~K}$ at $3 \mathrm{~s}$ after the initiation of heating. The accuracy of the present data is estimated to be +1.5 \%. The results were correlated by the following equation within the estimated accuracy.

Table 3 Experimental thermal Conductivities of Hitherm PS-5.

\begin{tabular}{cccc}
\hline \multirow{2}{*}{$\frac{T}{\mathrm{~K}}$} & \multicolumn{1}{c}{$\lambda$} & $\frac{T}{\mathrm{~K}}$ & $\frac{\lambda}{\mathrm{Wm}^{-1} \mathrm{~K}^{-1}}$ \\
300.50 & 0.1230 & 410.65 & 0.1126 \\
300.54 & 0.1228 & 410.67 & 0.1121 \\
300.58 & 0.1233 & 451.58 & 0.1094 \\
350.12 & 0.1186 & 451.70 & 0.1085 \\
350.17 & 0.1178 & 451.70 & 0.1083 \\
350.16 & 0.1187 & 493.00 & 0.1058 \\
410.74 & 0.1118 & 493.31 & 0.1053 \\
\hline
\end{tabular}

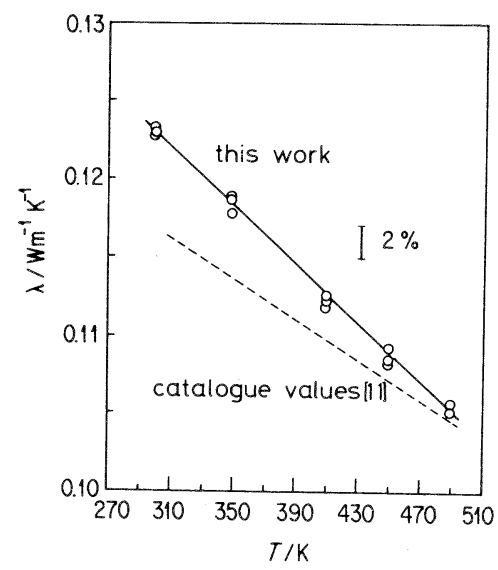

Fig. 7 Thermal conductivity of Hitherm PS -5 .

$$
\begin{array}{r}
\lambda / \mathrm{Wm}^{-1} \mathrm{~K}^{-1}=0.1508-9.27 \times 10^{-5} \times(T / \mathrm{K}) \\
300 \mathrm{~K}<T<493 \mathrm{~K} .
\end{array}
$$

In Fig. 7, the present thermal conductivity results on Hitherm PS-5 are compared with those taken from its catalogue [11]. Although the discrepancy amounts to more than 5 \% at low temperature range, this seems to be reasonable taking into account rather rough estimation method which might be used for the catalogue values.

3.2.2 slurry of pentaerythritol and Hitherm PS-5 The correlated equation on the thermal conductivity of pentaerythritol slurry is as follows;

$$
\begin{array}{rl}
\lambda / \mathrm{Wm}^{-1} \mathrm{~K}^{-1}=0.6631-8 & .272 \times 10^{-4} \times(T / \mathrm{K}) \\
& 296 \mathrm{~K}<\mathrm{T}<461 \mathrm{~K}, \\
\lambda / \mathrm{Wm}^{-1} \mathrm{~K}^{-1}=0.9086-1 . & 463 \times 10^{-3} \times(T / \mathrm{K}) \\
& 461 \mathrm{~K}<T<513 \mathrm{~K} .
\end{array}
$$

\begin{tabular}{|c|c|c|c|}
\hline$T$ & $\lambda$ & $T$ & $\bar{\lambda}$ \\
\hline K & $\mathrm{Wm}^{-1} \mathrm{~K}^{-1}$ & K & $\mathrm{Wm}^{-1} \mathrm{~K}^{-1}$ \\
\hline 296.15 & 0.4141 & 409.11 & 0.3246 \\
\hline 296.48 & 0.4150 & 409.10 & 0.3242 \\
\hline 296.74 & 0.4146 & 450.20 & 0.2887 \\
\hline 296.86 & 0.4150 & 450.24 & 0.2894 \\
\hline 332.73 & 0.3905 & 450.04 & 0.2890 \\
\hline 332.49 & 0.3902 & 450.07 & 0.2901 \\
\hline 332.09 & 0.3895 & 492.90 & 0.1898 \\
\hline 358.89 & 0.3679 & 492.91 & 0.1889 \\
\hline 358.94 & 0.3706 & 492.78 & 0.1838 \\
\hline 358.93 & 0.3711 & 513.33 & 0.1568 \\
\hline 358.81 & 0.3699 & 513.70 & 0.1577 \\
\hline 409.50 & 0.3231 & & \\
\hline
\end{tabular}

Table 4 Experimental thermal conductivities of pentaerythritol slurry.

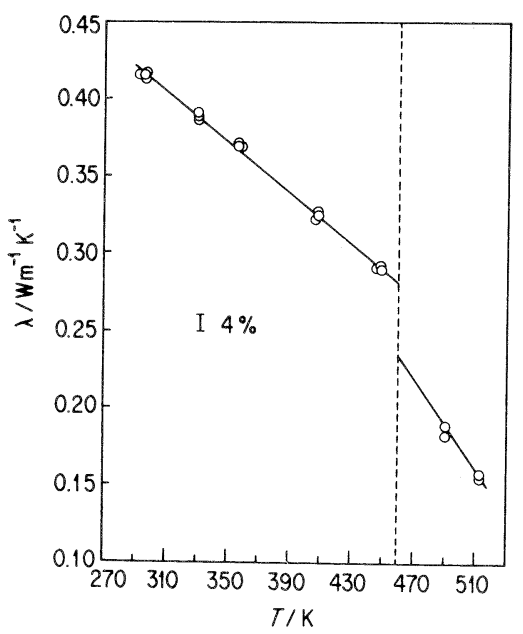

Fig. 8 Thermal conductivity of pentaerythritol slurry. 


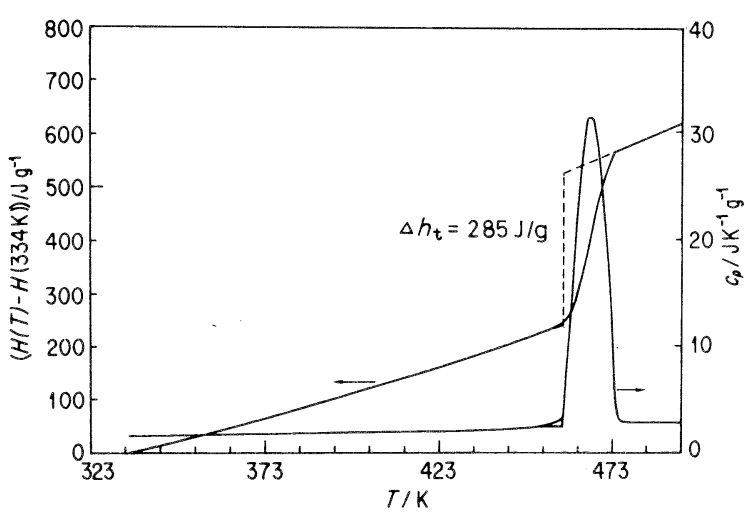

Fig. 4 Specific heat capacity data and the enthalpy change calculated from the data on pentaerythritol.

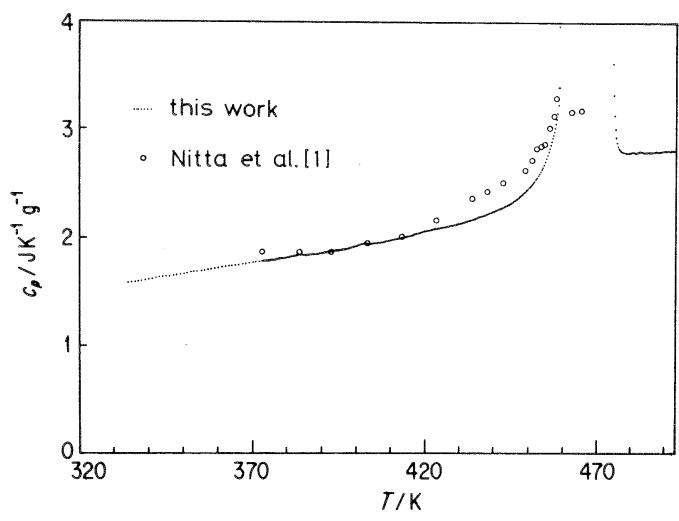

Fig. 5 specific heat capacity of pentaerythritol on an enlarged scale.

Table 1 Experimental specific heat capacities of pentaerythritol.

\begin{tabular}{ccccc}
\hline$T$ & $c_{p}$ & & $T$ & $c_{p}$ \\
\cline { 5 - 5 } & $\mathrm{JK}^{-1} \mathrm{~g}^{-1}$ & & $\mathrm{~K}$ & $\mathrm{JK}^{-1} \mathrm{~g}^{-1}$ \\
\hline 334 & 1.55 & 415 & 1.99 \\
335 & 1.56 & 420 & 2.04 \\
340 & 1.59 & 425 & 2.08 \\
345 & 1.61 & 430 & 2.12 \\
350 & 1.64 & 435 & 2.17 \\
355 & 1.66 & 440 & 2.24 \\
360 & 1.69 & 445 & 2.32 \\
365 & 1.71 & 450 & 2.44 \\
370 & 1.74 & 455 & 2.57 \\
375 & 1.75 & 460 & 6.82 \\
380 & 1.79 & 465 & 31.3 \\
385 & 1.82 & 470 & 25.4 \\
390 & 1.84 & 475 & 3.19 \\
395 & 1.86 & 480 & 2.77 \\
400 & 1.90 & 485 & 2.77 \\
405 & 1.92 & 490 & 2.77 \\
410 & 1.95 & 493 & 2.77 \\
\hline
\end{tabular}

lines of the enthalpy change at the extrapolated onset temperature.

Several values of heat of transition have been reported; they are between 269 and $322 \mathrm{~J} / \mathrm{g}[1-4]$. Nitta et al.[1] pointed out that the residual water in the sample might have a strong effect on the value of heat of transition. In the present study, it was measured for the dried sample and for the sample being kept for $8400 \mathrm{~h}$ under saturated vapor of water at room temperature. They did not show any difference. The scattering of the values reported by several investigators is therefore considered due to the difference in purity of the samples. From a scientific view point, the heat of transition of pentaerythritol has to be reexamined using an extra pure sample.

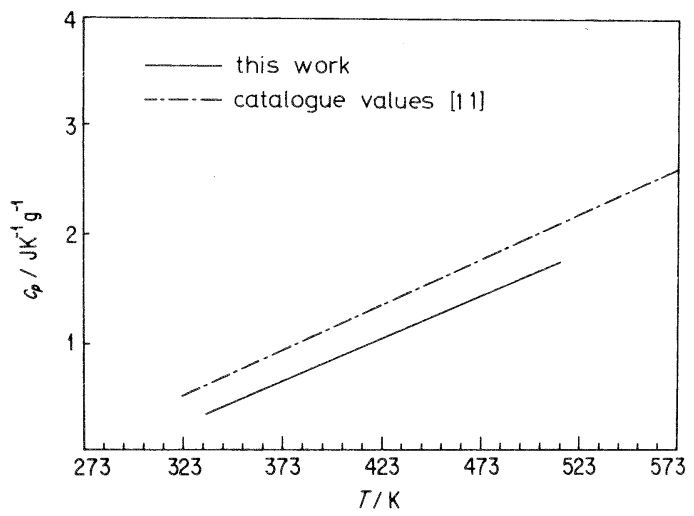

Fig. 6 Specific heat capacity of Hitherm PS-5.

Table 2 Experimental specific heat capacities of Hitherm PS-5.

\begin{tabular}{|c|c|c|c|}
\hline$T$ & ${ }^{c} p$ & $T$ & ${ }^{c} p$ \\
\hline $\mathrm{K}$ & $\mathrm{JK}^{-1} \mathrm{~g}^{-1}$ & K & $\mathrm{JK}^{-1} \mathrm{~g}^{-1}$ \\
\hline 334 & 1.80 & 425 & 2.13 \\
\hline 335 & 1.81 & 430 & 2.14 \\
\hline 340 & 1.85 & 435 & 2.15 \\
\hline 345 & 1.85 & 440 & 2.16 \\
\hline 350 & 1.87 & 445 & 2.20 \\
\hline 355 & 1.88 & 450 & 2.18 \\
\hline 360 & 1.88 & 455 & 2.21 \\
\hline 365 & 1.92 & 460 & 2.22 \\
\hline 370 & 1.93 & 465 & 2.24 \\
\hline 375 & 1.94 & 470 & 2.26 \\
\hline 380 & 1.95 & 475 & 2.27 \\
\hline 385 & 1.96 & 480 & 2.28 \\
\hline 390 & 1.98 & 485 & 2.29 \\
\hline 395 & 2.02 & 490 & 2.32 \\
\hline 400 & 2.03 & 495 & 2.34 \\
\hline 405 & 2.05 & 500 & 2.36 \\
\hline 410 & 2.07 & 505 & 2.37 \\
\hline 415 & 2.07 & 510 & 2.38 \\
\hline 420 & 2.10 & 513 & 2.38 \\
\hline
\end{tabular}


Figure 8 shows the results on the slurry of pentaerythritol and Hitherm PS-5. As seen from this figure, the thermal conductivity shows discontinuity at the phase transition temperature of pentaerythritol. The discontinuity. i.e. a decrease above the transition point, seems reasonable since the high temperature phase of pentaerythritol is a plastic crystal with disordered lattices, which causes an increase in phonon scattering.

\section{CONCLUDING REMARKS}

Heat capacity and heat of transition were measured by differential scanning calorimetry on pentaerythritol, which is a promising latent thermal storage material with transition temperature $188{ }^{\circ} \mathrm{C}$. Also measured was heat capacity and thermal conductivity of Hitherm PS-5, which is used to make slurry of pentaerythritol. The thermal conductivity was measured by the transient hot-wire method. It was applied to measure the thermal conductivity of the slurry of pentaerythritol and Hitherm PS -5 .

Both the heat capacity and thermal conductivity data were correlated by linear equations. The thermal conductivity of the slurry showed a discontinuity at the transition temperature due to a change in crystal structure.

The present data has been used to analyze the results of heat transfer experiments and to design latent thermal storage units using pentaerythritol slurry. The following R\&D are going on: (1) development of ways of stabilizing the slurry to prevent its adhesion to the containers etc. and (2) development of inexpensive encapsulation using materials which do not cause a degradation of pentaerythritol [6].

\section{ACKNOWLEDGMENT}

They express their deep appreciation to Dr. T. Ozawa for valuable discussion. The authors also thank Koei Chemical Co., Ltd. for providing the pentaerythritol sample.

\section{REFERENCES}

[1] I. Nitta, S. Seki, M. Momotani; Proc. Japan Acad., 26 (1950) $25 / 38$

[2] R. Sakamoto, M. Kamimoto, Y. Takahashi, Y. Abe, K. Kanari, T. Ozawa; Thermochim. Acta, 77(1984) $241 / 252$.

[3] E. Murill, L. Breed; Thermochim. Acta, 1 (1970) 239/246.

[4] D. K. Benson, R. W. Burrows, D. E. Artus; Proc. 11 th North American Thermal Analysis Soc. Conf., Vol. II (1981) 13/17.
[5] Y. Abe, R. Sakamoto, Y. Takahashi, M. Kamimoto, K. Kanari, T. Ozawa; Proc. 19th Intersoc. Energy Conv. Eng. Conf., (1984) 1120/1125.

[6] M. Kamimoto, Y. Abe, K. Kanari, S. Sawata, T. Tani, T. Ozawa; Proc. 21st Intersoc. Energy Conv. Eng. Conf., (1986) 730/736.

[7] Y. Takahashi; Thermochim. Acta, 88 (1985) 199/204.

[8] J.J. Healy, J. J. deGroot, J. Kestin; Physica, $82 \mathrm{C}$ (1976) $392 / 408$.

[9] N. Kawaguchi, Y. Nagasaka, A. Nagashima; Rev. Sci. Instrum., $56(1985) 1788 / 1794$.

[10] Y. Nagasaka, A. Nagashima; Proc. 1st Japan Symposium on Thermophysical Properties, (1981) 67/70.

[11] Nippon Oil Co. Ltd., "Hitherm".

[12] L. J. Rogers, A. G. Turnbull; Proc. 2nd Aust. Thermodyna. Conf, (1981) 436/444.

[13] R. W. Carling, L. G. Radosevich; Solar Energy, 22 (1979) $471 / 475$.

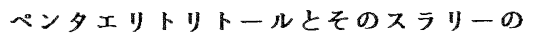

熱容量、転移熱、および熱伀導率

\author{
高橋義夫、神本正行、阿部宜之 \\ 電子技術総合研究所 \\ テ 305 茨城県つくば市梅園1-1-4 \\ 長坂雄次、長島 昭 \\ 慶応義塾大学理工学部機械工学科 \\ テ 223 横浜市港北区日吉 3-14-1
}

ペンタエリトリトールは $188^{\circ} \mathrm{C} に$ 転移点を有する 有望な潜熱蓄熱材料である。筆者らは、蓄熱材料側の 伝熱を促進するために、これを熱媒体油とスラリ一化 して用いる方法をいくつか提案している。本研究では、 ペンタエリトリトールおよび熱媒体油ハイサームP S - 5（アルキルジフェニルエタン）の熱容量および転 移熱を示差走查熱量湘定（D S C ）により測定した。 また、ハイサーム P S - 5、ならびにペンタエリトリ トールと八イサームP S - 5 のスラリーの熱伝導率を、 非定常細線法により測定した。熱容量と熱伝導率の測 定值の温度依存性は、ペンタエリトリトールの熱容量 を除き、直線でよく近似できた。スラリ一の熱伝導率 は、ペンタエリトリトールの相転移に伴う結晶構造の 変化のために転移点で不連続となり、転移点以上で小 さな値となることがわかった。

(Received on Dec. 19, 1987)

(Accepted for Publication on Jan. 26, 1988) 